\title{
Polyphenol Oxidase Activity and Inhibition in White Yam (Dioscorea Rotundata. Var. Laasirin) Chips as African Fries for Human Consumption
}

\author{
Oluwatoyin Oluwole, Olajumoke Odediran, Gbolahan Alagbe, Ijeoma Eboagwu, Abimbola Jegede, Kayode \\ Ogundeji, Abimbola Olokoshe, Godfrey Asieba and Joy Onyibe \\ Federal Institute of Industrial Research Oshodi, Lagos, Nigeria
}

\begin{abstract}
Polyphenol oxidase, a bi-functional enzyme, has been implicated in enzymatic browning of yam and other tubers in a negative way. The objective of this present study was to examine the activity of polyphenol oxidase in Dioscorea rotundata. Var. laasirin and the efficiency of heat and chemical treatments in inhibiting this enzyme. Crude Polyphenol Oxidase (PPO) of Dioscorea rotundata.Var. Laasirin was isolated and the kinetics studied using the lineweaver-burk plot. The activity of the enzyme was evaluated using spectrophotomeric method. Yam PPO catalyzes oxidation of various substrates with catechol being the most readily oxidized substrate. The Michaelis-Menten constant $(\mathrm{Km})$ and maximum reaction velocity (Vmax) for yam PPO were 0.00037 and 0.3125 respectively. Inhibition data showed that the enzyme had least activity (71.70) when blanched at $95{ }^{\circ} \mathrm{C}$ for 7 mins with chemical treatment involving a combination of $0.5 \%$ Sodium metabisulphite (Food grade) and $0.5 \%$ Ascorbic acid (Food grade). The activity was highest (83.02) when it was blanched at $95{ }^{\circ} \mathrm{C}$ for 7 mins. This study has shown that it is possible to inhibit polyphenol oxidase activity in white yam using the chemical pretreatments and processing conditions described in this study for possible adoption in the production of packaged frozen yam chips by food industries.
\end{abstract}

Key words: Yam, polyphenol oxidase, dioscorea rotundata, blanch, sulphite, chips.

\section{Introduction}

Yam is a major staple food in Nigeria and in many tropical countries, where many varieties are cultivated. Much of the yam cultivated is consumed fresh and it is traditionally consumed as boiled or pounded yam. Yam tubers are usually stored under ambient tropical conditions, and due to its high moisture content, changes in wholesomeness occur under such conditions $[1,2]$. The annual production of yam is about 37.5 million tons and Nigeria contributes for about $70 \%$ of the total world production [3]. In recent years French fries have become popular in fast food restaurants in many tropical and, developing countries where yams are also produced in large quantities. Potatoes, which traditionally are used for French fries production, are not locally available in many of these

Corresponding author: Oluwatoyin Bolanle Oluwole, Ph.D., research fields: food processing and storage technology. countries thus making them an expensive food. The use of yam as a substitute for potato in French fries production, will not only make the fries more affordable, but will also help to reduce postharvest losses and enhance its distribution network.

Polyphenol oxidase, a bi-functional enzyme, which has been implicated in enzymatic browning contains copper in its structure, has been described as an oxygen and four electron transferring phenol oxidase [4]. PPO (EC 1.10.3.1; o-diphenol oxidoreductase) is an oxidoreductase able to oxidize phenol compounds, employing oxygen as a hydrogen acceptor. The abundance of phenolics in plants may be the reason for naming this enzyme PPO [5]. The molecular weight for PPO in plants ranges between 57 and 62 $\mathrm{kDa}[6,7]$. PPO catalyzes two basic reactions: hydroxylation to theo-position adjacent to an existing hydroxyl group of the phenolic substrate (monophenol 
oxidase activity) and oxidation of diphenol too benzoquinones (DPO activity).

Enzymatic browning reactions may affect fruits, vegetables, tubers and seafood in either positive or negative ways. These reactions, for instance, may contribute to the overall acceptability of foods such as tea, coffee, cocoa, and dried fruits (raisins, prunes, dates, and Figs.) and in other cases may cause a decrease in the market value of food products originating from plants and crustaceans [8-12]. Processing such as cutting, peeling, and bruising is enough to cause enzymatic browning. The rate of enzymatic browning is governed by the active PPO content of the tissues, the phenolic content of the tissue, and the $\mathrm{pH}$, temperature, and oxygen availability within the tissue. The inhibition of enzymatic browning generally proceeds via direct inhibition of the PPO, nonenzymatic reduction of o-quinones, and chemical modification or removal of phenolic substrates of PPO. Among all these methods, inhibition of PPO is preferable. There are six categories of PPO inhibitors applicable to control enzymatic browning: reducing agents, acidulants, chelating agents, complexing agents, enzyme inhibitors, and enzyme treatments [5].

PPO inhibitors from natural and synthetic sources have been reported [5]. Sulfites are the most efficient multifunctional agents in the control of enzymatic browning of foods. However, the most efficient way to control this problem is the combination of physical and chemical methods, by avoiding the use of more severe individual treatments, which could harm the appearance and texture of the processed food. Technological processing, including microwave blanching either alone or combined with chemical anti-browning agents [13-16]; or natural anti-browning agents like pineapple juice [17], onion juice [18], onion oil [19], onion extracts [20], onion by-products (residues and surpluses) is also commonly used [21].

The objective of this present study is to examine the activity of polyphenol oxidase in Dioscorea rotundata. Var. laasirin, the efficiency of heat and chemical treatments in inhibiting this enzyme, sensory qualities of African fries produced from this variant and the acceptability of these fries by consumers.

\section{Methodology and Project Components/Activities}

\subsection{Obtaining Yam}

For this research, yam farmers provided appropriate samples (void of rotting, excessive sprouting and mechanical damage) for the experiment.

\subsection{Peeling and Trimming}

The yield of French fries is governed mainly by peeling, trimming and cutting methods and the size and shape of the tuber. Peeled and washed yam were inspected to remove sub-standard tubers, while those with minor (visible) defects were trimmed.

\subsection{Blanching and Chemical Treatment}

Hot water blanching at $95{ }^{\circ} \mathrm{C}$ for 7 mins and chemical treatments using $0.5 \%$ Sodium metabisulphite (Food grade) and $0.5 \%$ Ascorbic acid (Food grade) solution was carried out on the samples to prevent enzymatic browning. Some samples were blanched only and labelled BOX, some others were chemically treated only and labelled XOX while a third set was both blanched and chemically treated and labelled BXX.

\subsection{Biochemical Analysis}

2.4.1 Preparation of Crude Extract of Polyphenol Oxidase

Ten grams of the plant samples were washed and cut into a $10 \mathrm{~g} / \mathrm{L}$ ice cold sodium sulphite solution and allowed to stand for 20 minutes. After soaking, the sodium sulphite solution was decanted and the cut sample subsequently washed thoroughly with distilled water. The samples were blended in $20 \mathrm{~mL}$ phosphate buffer $(\mathrm{pH}=7)$ for 3 minutes. The resulting 
homogenate was quickly squeezed through two layers of clean cheese cloth into a beaker kept in ice. The crude extract was filtered through Whatman No. 1 filter paper. The separated filtrate was subsequently centrifuged at $1,000 \mathrm{~g}$ for 10 minutes. The supernatant constituted the crude enzyme extract of polyphenoloxidase.

2.4.2 Determination of Polyphenol Oxidase Activity

The activity of polyphenol oxidase was determined based on the methods of Vamos-Vigyazo [22-25]. Serial dilutions of $0.012 \mathrm{M}, 0.006 \mathrm{M}, 0.003 \mathrm{M}, 0.0015$ $\mathrm{M}$ and $0.00075 \mathrm{M}$ were prepared from a stock solution of $0.024 \mathrm{M}$ of catechol. To each test tube corresponding concentrations of $1 \mathrm{~mL}$ of catechol solution was added. It was followed by the addition of $1 \mathrm{~mL}$ of $0.1 \mathrm{M}$ phosphate buffer $(\mathrm{pH}=7.0)$. A $3 \mathrm{~mL}$ distilled water was added and the enzyme reaction started by the introduction of $0.5 \mathrm{~mL}$ of the enzyme extract of polyphenol oxidase. The mixture was quickly transferred into a cuvette and the change in absorbance was monitored spectrophotometrically at $\lambda \max =540 \mathrm{~nm}$ at a regular interval of 30 seconds.

\subsubsection{Determination of Kinetic Parameters}

The enzyme kinetic parameters, Michaelis-Menten constant $(\mathrm{Km})$ and maximum reaction velocity (Vmax) for yam PPO were determined at $25^{\circ} \mathrm{C}$ when using catechol as substrates. They were assayed in different concentrations, and at the optimum $\mathrm{pH}$ and wavelength for catechol. The assay cuvette $(2 \mathrm{~mL})$ contained $0.8 \mathrm{~mL}$ of catechol (prepared in $10 \mathrm{mM}$ sodium phosphate buffer, $\mathrm{pH}$ 6.0) solution with gradient concentration and $0.1 \mathrm{~mL}$ of the enzyme solution, respectively. Data were plotted as 1 /activity and $1 /$ substrate concentration according to the method of Lineweaver and Burk [26]. Substrate specificity $(\mathrm{Vmax} / \mathrm{Km})$ was calculated by using Lineweaver-Burk equation;

$$
\begin{aligned}
& \underline{1}=\underline{\mathrm{Km}}+\underline{1} \\
& \mathrm{~V}_{0} \mathrm{Vmax}[\mathrm{S}] \mathrm{V} \max \\
& \text { Slope }=\underline{\mathrm{Km}} \\
& \mathrm{Vmax}
\end{aligned}
$$

The data obtained were plotted on Fig. 1.

2.4.4 Calculation of Percentage Activity in Treated Samples

The percentage activity of polyphenol oxidase enzyme in the treated samples was calculated using the formula;

$\%$ Activity $=$ Activity of PPO in treated sample $\times 100$

Activity of PPO in untreated sample

\subsection{Nutritional Analysis}

The recommended method of association of analytical chemists (AOAC, 1990) was used for the determination of moisture, ash, crude lipid, crude fibre and nitrogen content. Crude protein was estimated by multiplying the sample percentage nitrogen content by a factor 6.25. Available carbohydrate was calculated by difference by subtracting total sum of crude protein, crude lipid, crude fibre and ash from 100\% DW sample (AOAC, 1990). The sample calorific value was estimated (in kcal) by multiplying the percentages of crude protein, crude lipid and carbohydrate by the recommended factors $(2.44,8.37$ and 3.57 respectively) used in vegetables analysis [27].

\subsection{Frying Characteristics of Yam Chips}

To determine the appropriate frying time of the chips after treatment and freezing, the chips were poured into hot oil at $170{ }^{\circ} \mathrm{C}$ and withdrawn at intervals of 3 minutes till the desired texture and crispiness was attained. The moisture content of the chips was also determined at each interval. The moisture content was determined in the chips using a rapid moisture analyzer (Sartorious MA 30).

\subsection{Organoleptic Qualities of Fried Chips}

The treated and frozen yam chips were fried and subjected to organoleptic tests using semi-trained panelists in the Institute based on established procedures. Frozen potato chips and fresh untreated yam were both fried and were used as controls. A 20 member panelist was used, involving a 9-point 
hedonic scale. Where 1 represented "dislike extremely" and 9 represented "extremely acceptable". Parameters determined were taste, after taste, mouth feel, color, appearance, flavor, off-flavor, crispiness, and overall acceptability. The results obtained were subjected to statistical analysis using SPSS (Statistical Package for the Social Sciences) Version 16 for PC Windows. All data were subjected to Analysis of Variance (ANOVA) and means were separated using Duncan's Multiple Range Test (DMRT).

\subsection{Consumer Acceptability Survey}

Consumers' responses were evaluated in a survey of 200 haphazardly selected people from three Local Government Areas (LGAs) in Lagos state, Nigeria. The Local Government Areas included in this study are Oshodi Isolo LGA, Mushin LGA and Alimosho LGA, Lagos. The method used by FAO/IAEA [28] was modified and adapted for this study. The yam chips developed in the laboratory was produced and given to the selected people to consume. A set of questionnaire was administered immediately on the sample to ascertain their perception of the product. Quantitative analytical tools such as percentages and Likert scale were used to analyse the data.

\subsection{Statistical Analysis}

Analysis of variance (ANOVA) was obtained using the Microsoft Excel (version 13) statistical computer program. Evaluations were based on the $p$-value $<$ 0.05 significance. Graphical comparism of the inhibition achieved by each treatment was also carried out using the Microsoft Excel (version 13) statistical computer program.

\section{Results}

\subsection{Polyphenol Oxidase Activity}

The activity of polyphenol oxidase in all the treatments given is recorded in Table 1. It is observed that the activity of polyphenol oxidase reduced with increase in time across all concentrations in the entire treated sample. However, the lower the concentration of catechol, which is the substrate of the enzyme, the higher the activity of the polyphenol oxidase enzyme.

\subsection{Statistical Analysis of Polyphenol Oxidase Activity}

The analysis of variance amongst all the treatments is recorded in Table 2. The $p$-value recorded at all the time intervals is $<0.05$ thus indicating that there is significant difference in the activity of polyphenol oxidase between the different treatment methods.

\subsection{Kinetic Parameters}

The Vmax is the velocity approached at a saturating concentration of substrate. Vmax has the same units as $\mathrm{v}$ while $\mathrm{Km}$ is the concentration of substrate required to produce a velocity that is one-half of Vmax. From Fig. 1 below we can see that $1 / \mathrm{Vmax}=3.2$ while $1 / \mathrm{Km}=-2700$. When the inverse is calculated, Vmax $=0.3125$ while $\mathrm{Km}=0.00037$. The slope $=0.0012$.

\subsection{Inhibition of Polyphenol Oxidase in All Treatments}

The comparism of polyphenol oxidase inhibition amongst the various treatments was carried out and shown in Fig. 2. It was observed that the highest

\section{Table 1 Percentage activity of polyphenol oxidase in treated samples.}

\begin{tabular}{|c|c|c|c|c|c|c|c|c|c|c|c|c|c|c|c|}
\hline \multirow{3}{*}{$\begin{array}{l}\text { Time } \\
\text { (s) }\end{array}$} & \multicolumn{15}{|c|}{ Concentrations of Cathecol across the treatments } \\
\hline & \multicolumn{3}{|c|}{$0.012 \mathrm{M}$} & \multicolumn{3}{|c|}{$0.006 \mathrm{M}$} & \multicolumn{3}{|c|}{$0.003 \mathrm{M}$} & \multicolumn{3}{|c|}{$0.0015 \mathrm{M}$} & \multicolumn{3}{|c|}{$0.00075 \mathrm{M}$} \\
\hline & $\mathrm{BOX}$ & $\mathrm{XOX}$ & $\mathrm{BXX}$ & $\mathrm{BOX}$ & $\mathrm{XOX}$ & $\mathrm{BXX}$ & BOX & $\mathrm{XOX}$ & $\mathrm{BXX}$ & $\mathrm{BOX}$ & $\mathrm{XOX}$ & $\mathrm{BXX}$ & BOX & $\mathrm{XOX}$ & BXX \\
\hline 30 & 83.02 & 77.90 & 71.70 & 91.17 & 84.10 & 84.81 & 109.45 & 96.06 & 77.95 & 133.78 & 114.22 & 112.44 & 114.48 & 103.62 & 97.74 \\
\hline 60 & 83.38 & 78.55 & 72.12 & 88.70 & 81.85 & 82.88 & 107.69 & 94.62 & 75.77 & 135.75 & 116.74 & 115.38 & 117.35 & 105.02 & 98.63 \\
\hline 90 & 78.99 & 74.43 & 66.08 & 86.67 & 79.67 & 81.33 & 105.26 & 92.86 & 74.44 & 133.04 & 114.54 & 110.57 & 114.80 & 103.59 & 96.41 \\
\hline 120 & 72.62 & 68.91 & 60.56 & 84.47 & 77.99 & 78.96 & 102.56 & 90.11 & 72.89 & 131.30 & 115.65 & 109.57 & 88.58 & 80.62 & 74.05 \\
\hline 150 & 74.29 & 72.14 & 61.90 & 80.88 & 76.50 & 76.49 & 100.72 & 88.17 & 71.33 & 131.60 & 115.58 & 108.23 & 87.03 & 79.52 & 73.04 \\
\hline 180 & 72.39 & 71.46 & 60.32 & 78.42 & 75.08 & 74.16 & 98.25 & 86.01 & 69.58 & 130.77 & 114.53 & 106.84 & 86.73 & 79.25 & 72.79 \\
\hline
\end{tabular}


Table 2 Analysis of variance of BOX, XOX and BXX at 30 secs time intervals.

\begin{tabular}{lllllll}
\hline Time (s) & SS & Df & MS & $F$-value & $P$-value & $F$ crit \\
\hline 30 & 2464.688 & 4 & 616.1719 & 6.983575 & 0.003826 & 3.259167 \\
60 & 2907.666 & 4 & 726.9166 & 7.147078 & 0.00349 & 3.259167 \\
90 & 3011.785 & 4 & 752.9462 & 7.298432 & 0.00321 & 3.259167 \\
120 & 3327.685 & 4 & 831.9214 & 7.613484 & 0.002705 & 3.259167 \\
150 & 3217.73 & 4 & 804.4324 & 7.460912 & 0.002937 & 3.259167 \\
180 & 3257.901 & 4 & 814.4752 & 7.466268 & 0.002928 & 3.259167 \\
\hline
\end{tabular}

$\mathrm{SS}=$ sum of square; $\mathrm{df}=$ degree of freedom; $\mathrm{MS}=$ mean square.

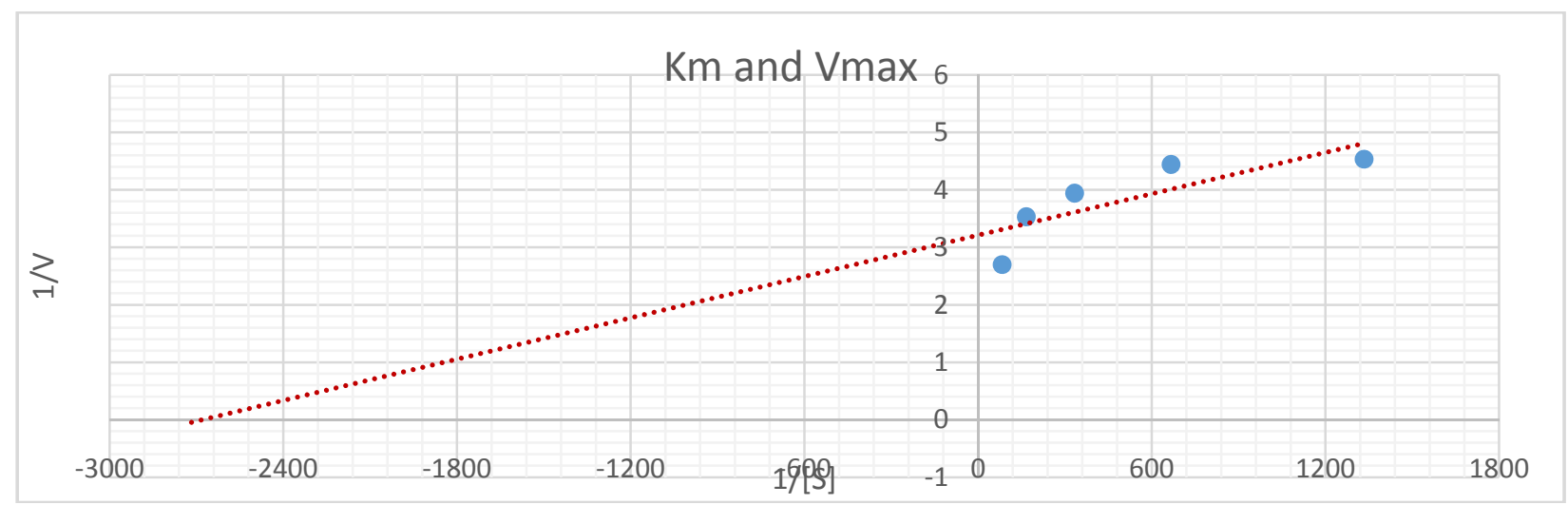

Fig. 1 1/Km and 1/Vmax determination using Lineweaver burk plot.

\section{Comparism of inhibition occuring amongst treated samples}

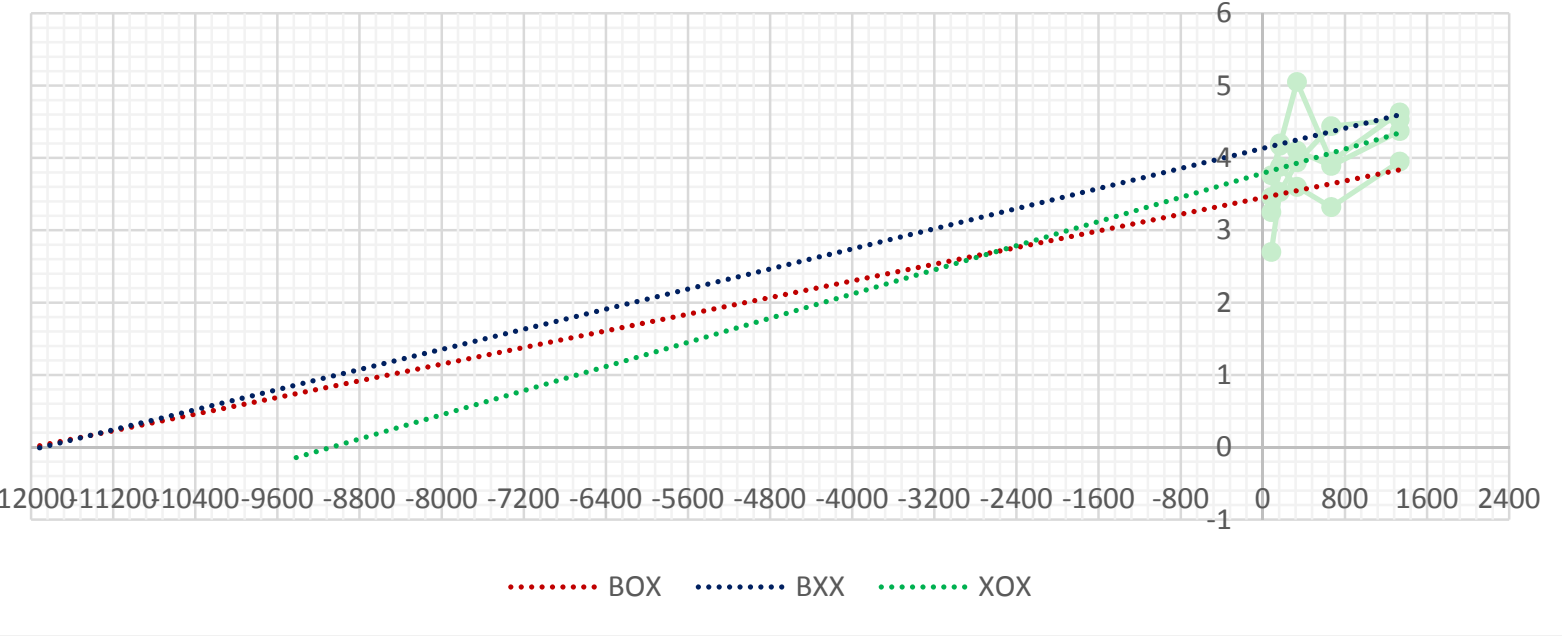

Fig. 2 Comparism of polyphenol oxidase inhibition between all treated samples.

inhibition occurred in the blanched and chemically treated (using sodium metabisulphite and ascorbic acid) sample followed by the chemically treated (using sodium metabisulphite and ascorbic acid) sample then the sample that received only blanching treatment. This shows that a combination of blanching and chemically treatment was the most effective for inhibition of PPO in this variant of Dioscorea rotundata. A similar observation has been reported in which a combination of physical and chemical treatments was proven to be most effective in the inhibition of PPO on lettuce [13]. The results obtained are also in line with a study where it was observed that PPO from Dioscorea cayenensis-rotundata cv. 
Zrèzrou was inhibited by betamercaptoethanol, sodium thiosulphate, ascorbic acid, sodium bisulphate, DL-dithiothreitol, DTNB, EDTA and cysteine [29]. It is also in line with a study which reported that heat treatments are effective in the inhibition of PPO in mushroom [30].

\subsection{Nutritional Analysis}

Table 3 shows the nutritional values of frozen Dioscorea rotundata Var. Laasirin specie of yam. The carbohydrates and protein content is higher than the reported values of frozen potato obtained from literature (19.28\% and $1.91 \%$ respectively) [31]. However, the fibre and fat contents are lower than the reported values of frozen potato obtained from literature (1.22\% and $0.09 \%$ respectively) [31].

\subsection{Frying Characteristics of Yam Chips}

The moisture content of fresh $D$. rotundata (white yam) was $72.10 \%$ (Table 1). Frying made the yam chips edible and was also a dehydration process, as the heat transferred by the hot oil into the yams during frying provided enough energy for vaporization of moisture from the yam chips. The result in Table 4 shows that the moisture content of white yam was $52.58 \%$ after frying for three minutes and $32.47 \%$ by the eighteenth minute. This shows that the frying time is inversely proportional to the moisture content, as the moisture content decreases when frying time is increased.

\subsection{Organoleptic Analysis}

The pre-treated frozen yam chips produced from Dioscorea rotundata Var. Laasirin gave some desirable sensory characteristics when fried as organoleptic analysis values indicated that there was no significant difference in the colour and overall acceptability of the frozen yam chips when compared to fresh yam and frozen potato chips when fried. Organoleptic analysis values also indicate that the frozen yam chips was preferred in terms of crispiness and had no significant difference to frozen potato chips in terms of taste and mouthfeel.

\subsection{Consumer Acceptability}

Analysis revealed that almost all the respondents (97\%) had knowledge of yam being chipped and used as fries however less than half of the respondents (42\%) had consumed yam chipped and used for fries. Almost all the respondents (95\%) were satisfied with the pre-treated and frozen chipped yam used as fries and the same amount of respondents (95\%) were willing to continue consumption of the pre-treated and frozen chipped yam used as fries.

Table 3 Nutritional values of chemically and heat treated frozen Dioscorea rotundata Var. Laasirin.

\begin{tabular}{ll}
\hline Parameters & Values obtained \\
\hline Calorific content & 93.75 Kcal \\
$\%$ Carbohydrates & 24.77 \\
$\%$ Protein & 2.05 \\
$\%$ Fibre & 0.40 \\
$\%$ Fat (Trans-free) & 0.06 \\
$\%$ Moisture & 72.10 \\
\hline
\end{tabular}

Table 4 Frying characteristics of yam chips.

\begin{tabular}{ll}
\hline Frying time (mins) & White yam (\%) \\
\hline 0 & 72.10 \\
3 & 52.58 \\
6 & 45.52 \\
9 & 41.30 \\
12 & 35.76 \\
15 & 32.47 \\
\hline
\end{tabular}

Table 5 Mean sensory scores of fried yam chips.

\begin{tabular}{llllllllll}
\hline Sample & Colour & Appearance & Taste & After taste & Flavour & Off flavour & Crispiness & Mouth feel & $\begin{array}{l}\text { Overall } \\
\text { acceptability }\end{array}$ \\
\hline Fresh yam chips & $8.07^{\mathrm{a}}$ & $7.73^{\mathrm{a}}$ & $7.93^{\mathrm{a}}$ & $7.40^{\mathrm{a}}$ & $7.73^{\mathrm{a}}$ & $6.4^{\mathrm{a}}$ & $6.40^{\mathrm{ab}}$ & $7.40^{\mathrm{a}}$ & $6.40^{\mathrm{a}}$ \\
$\begin{array}{l}\text { Frozen yam chips } \\
7.27^{\mathrm{a}}\end{array}$ & $6.60^{\mathrm{b}}$ & $6.0^{\mathrm{b}}$ & $5.93^{\mathrm{b}}$ & $6.07^{\mathrm{b}}$ & $4.87^{\mathrm{a}}$ & $7.07^{\mathrm{a}}$ & $5.87^{\mathrm{b}}$ & $4.93^{\mathrm{a}}$ \\
$\begin{array}{l}\text { Frozen potato } \\
\text { chips }\end{array}$ & $7.87^{\mathrm{a}}$ & $7.53^{\mathrm{ab}}$ & $6.33^{\mathrm{b}}$ & $6.27^{\mathrm{ab}}$ & $7.07^{\mathrm{ab}}$ & $5.67^{\mathrm{a}}$ & $5.27^{\mathrm{b}}$ & $5.80^{\mathrm{b}}$ & $5.53^{\mathrm{a}}$ \\
\hline
\end{tabular}

Values in the same row with the same superscript are not significantly different at 5\% probability level. 
Table 6 Survey of consumer acceptability of the chipped and frozen Dioscorea rotundata Var. Laasirin used as African fries.

\begin{tabular}{lcc}
\hline Items surveyed & RESPONSE \\
\cline { 2 - 3 } & Number & Percentage \\
\hline Knowledge of yam chipped and used as fries: & \\
Have you heard of yam chipped used as fries? & 194 & 97 \\
Yes & 6 & 3 \\
No & & 42 \\
Have you consumed yam chipped and used as fries? & 84 & 58 \\
Yes & 116 \\
No &
\end{tabular}

Satisfaction derived from pre-treated and frozen chipped yam used as fries:

Are you satisfied with the pre-treated and frozen chipped yam fries you are presented with?

Yes $\quad \begin{array}{lll}90 & 95\end{array}$

$\begin{array}{lcc}\text { No } & 10 & 5\end{array}$

$\begin{array}{ll}\text { What is the basis of your satisfaction? } & 58 \quad 29\end{array}$

$\begin{array}{lrr}\text { Aroma } & 38 & 38\end{array}$

$\begin{array}{lrr}\text { Color } & 56 & 28\end{array}$

All of the above

$48 \quad 24$

Willingness to continue consumption of the pre-treated and frozen yam chips used as fries:

Will you like to continue eating the pre-treated and frozen chipped yam fries you are presented with?

Yes

No

$190 \quad 95$

$10 \quad 5$

\section{Conclusion}

Yam, like potato could be processed and distributed as frozen yam chips for production of French fries. $0.5 \%$ Ascorbic acid and $0.5 \%$ Sodium metabisulphite treatment with hot water blanching at $95{ }^{\circ} \mathrm{C}$ for 7 minutes were effective in reducing PPO activity and preventing enzymatic browning in Dioscorea rotundata. Var. laasirin. Critical attention must be given to the combined treatment of Ascorbic acid and Sodium metabisulphite with hot water blanching as it is an important pre-process activity for frozen yam chips.

\section{References}

[1] Afoakwa, E. O., and Sefa-Dedeh, S. 2001. "Changes in Rheological Properties and Amylase Activities of Trifoliate Yam, Dioscorea Dumetorum, Starch after Harvest." Food Chemistry 77: 285-91.

[2] Sefa-Dedeh, S., and Afoakwa, E. O. 2002. "Biochemical and Textural Changes in Trifoliate Yam Dioscorea Dumetorum Tubers after Harvest." Food Chemistry 79: 27-40.

[3] Food and Agriculture Organisation FAO. 2006. FOASTAT. FAO Statistics Division, Rome.

[4] Jolley, R. L. 1974. “Oxytyrosinase.” J. Biol. Chem. 249 (2): 335-45.

[5] Marshall, M. R., Kim, J., and Wei, C. 2000. "Enzymatic
Browning in Fruits, Vegetables and Seafoods." FAO report, Accessed on August 12, 2011, http://www.fao.org/ag/ags/agsi/ENZYMEFINAL/.

[6] Hunt, M. D., Eannetta, N. T., Yu, H., Newman, S. M., and Steffens, J. C. 1993. "cDNA Cloning and Expression of Potato Polyphenol Oxidase." Plant Mo1. Biol. 21: 59-68.

[7] Newman, S. M., Eannetta, N. T., Yu, H., Prince, J. P., de Vicente, M. C., Tanksley, S. D., and Steffens, J. C. 1993. "Organisation of the Tomato Polyphenol Oxidase Gene Family." Plant Mo1. Biol. 21: 1035-51.

[8] Kubo, I., Kinst-Hori, I., Kubo, Y., Yamagiwa, Y., Kamikawa, T., and Haraguchi, H. 2000. "Molecular Design of Antibrowning Agents." J. Agric. Food Chem. 48: 1393-9.

[9] Perez-Gilabert, M., and Carmona, F. G. 2000. "Characterization of Catecholase and Cresolase Activities of Eggplant Polyphenol Oxidase." J. Agric. Food Chem. 48: 695-700.

[10] Subaric, D. 2001. "Effectiveness of Some Crown Compounds on Inhibition of Polyphenoloxidase in Model Systems and in Apple." Acta Alimentaria 30 (1): 81-7.

[11] Yoruk, R., and Marshall, M. R. 2003. "Physicochemical Properties and Function of Plant Polyphenol Oxidase: A Review." J. Food Biochem. 27: 361-422.

[12] Queiroz, C., Mendes Lopes, M. L., Fialho, E., and Valente-Mesquita, V. L. 2008. "Polyphenol Oxidase: Characteristics and Mechanisms of Browning Control." Food Reviews International 24 (4): 361-75.

[13] Severini, C. 2001. "Preventing Enzymic Browning of Potato by Microwave Blanching." Sci. des Aliments 21 
(2): 149-60.

[14] Premakumar, K, and Khurduya, D. S. 2002. "Effect of Microwave Blanching on Nutritional Qualities of Banana Puree." J. Food Sci. Technol Mysore 39 (3): 258-60.

[15] Yadav, D. N. 2008. "Effect of Microwave Heating of Wheat Grains on the Browning of Dough and Quality Chapattis.” Int. J. Food Sci 43 (7): 1217-25.

[16] Guan, W. Q., and Fan, X. T. 2010. "Combination of Sodium Chlorite and Calcium Propionate Reduces Enzymatic Browning and Microbial Population of Fresh-Cut 'Granny Smith' Apples.” J. Food Sci. 75 (2): 72-7.

[17] Perera, N. 2010. "Colour and Texture of Apples High Pressure Processed in Pineapple Juice.” Innovative Food Sci. Emerg Technol 11 (1): 39-46.

[18] Hosoda, H., and Iwahashi, I. 2002. "Inhibition of Browning If Apple Slice and Juice by Onion Juice." J. Jpn. Soc. Hortic Sci. 71 (3): 452-4.

[19] Hosoda, H. 2003. "Inhibitory Effect of Onion Oil on Browning of Shredded Lettuce and Its Active Components.” J. Jpn Soc. Hortic Sci. 75 (5): 451-6.

[20] Kim, M. J., Kim, C. Y., and Park, I. 2005. "Prevention of Enzymatic Browning of Pear by Onion Extract." Food Chem. 89: 181-4.

[21] Roldan, E. 2008. "Characterisation of Onion (Allium cepa L.) by Products as Food Ingredients with Antioxidant and Antibrowning Properties." Food Chem. 108 (3): 907-16.

[22] Vamos-Vigyazo, L. 1981. "Polyphenol Oxidase and Peroxidase in Fruits and Vegetables." CRC Crit. Rev. Food Sci. Nutr. 15: 49-127.

[23] Vamos-Vigyazo, L., Mihalyi, K., Gajzago, I., and Nadudvari-Markus. V. 1977. "The Role of Enzyme-Substrate Ratio in the Enzymatic Browning of Fruit Tissue Homogenates.” Acta Alimentaria 6: 379-88.
[24] Vamos-Vigyazo, L., and Nadudvari-Markus, V. 1982. "Enzymatic Browning, Polyphenol Oxidase and Peroxidase in Pearcultivars." Acta Alimentaria 11: 157-64.

[25] Vamos-Vigyazo, L., and Nadudvari-Marlcus, V. 1983. "Inactivation of Polypheno 1 Oxidase and Depletion of O-Dihydroxyphenol Content during the Enzymatic Browning Reaction of Fruit Tissues." Acta Alimentaria 12: 1-9.

[26] Lineweaver, H., and Burk, D. 1934. "The Determination of Enzyme Dissociation Constants." Journal of the American Chemical Society 56 (3): 658-66.

[27] Asibey-Berko, E., and Taiye, F. A. K. 1999. "Proximate Analysis of Some Underutilized Ghanian Vegetables." Ghana Journal of Science 39: 91-2.

[28] FAO/IAEA Division of Nuclear Techniques in Food and Agriculture. 1998. "Consumer Acceptance and Market Development of Irradiated Food in Asia and the Pacific." In Proceedings of a Final Research Co-ordination Meeting, held in Bangkok, Thailand, September 21-25, 1998 IAEA-TECDOC-1219.

[29] Judicael, K., Gnangui, S. N., Dabonné, S., and Kouamé, L. P. 2015. "Isolation of a Latent Polyphenol Oxidase from Edible Yam (Dioscorea cayenensis-rotundata cv. Zrèzrou) Cultivated in Côte D'ivoire." Journal of Advances in Biology \& Biotechonology 2 (4): XX-XX.

[30] Weemaes, C. A., De Cordt, S. V., Ludikhuyze, L. R., Van den Broeck, I., Hendrickx, M. E., and Tobback, P. P. 1997. "Influence of $\mathrm{pH}$, Benzoic Acid, EDTA, and Glutathione on the Pressure and or Temperature Inactivation Kinetics of Mushroom Polyphenoloxidase." Biotechnology Progress 13 (1): 25-32.

[31] Abong, G. O., Okoth, M. W., Imungi, J. K., and Kabira, J. N. 2009. "Evaluation of Selected Kenyan Potato Cultivars for Processing into Potato Crisps." Agriculture and Biology Journal of North America 1 (5): 886-93. 